\title{
Historein
}

Vol 15, No $1(2015)$

Revisiting Democratic Transitions in Times of Crisis

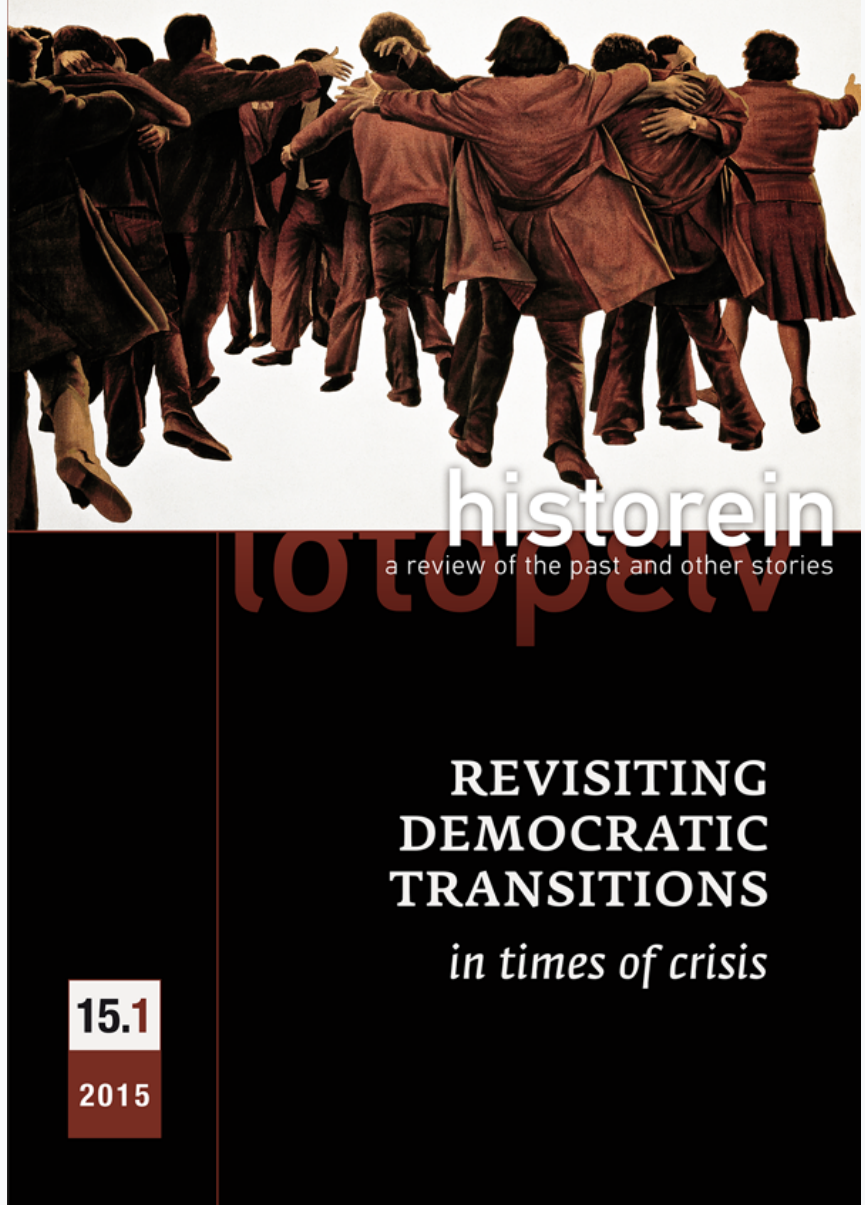

The use of transitology in the field of transitional justice: a critique of the literature on the 'third wave' of democratisation

Raluca Grosescu

doi: $10.12681 /$ historein.272

Copyright @ 2015, Raluca Grosescu

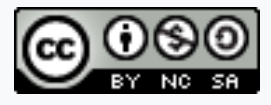

This work is licensed under a Creative Commons Attribution-NonCommercialShareAlike 4.0.

To cite this article:

Grosescu, R. (2015). The use of transitology in the field of transitional justice: a critique of the literature on the 'third wave' of democratisation. Historein, 15(1), 102-116. https://doi.org/10.12681/historein.272 


\section{The use of transitology in the field of transitional justice: a critique of the literature on the 'third wave' of democratisation}

\section{Raluca Grosescu}

University of Exeter
In the 1990s, transitional justice emerged as an academic discipline at the intersection of theories of democratic transitions (or transitology) ${ }^{1}$ and international human rights law. ${ }^{2}$ While the origins of the field can be traced back to the 1960s in scholarship addressing the purges and trials held after the Second World War, ${ }^{3}$ the term and concept "transitional justice" were coined in the particular context of the "third wave" of democratisation. ${ }^{4}$ They referred to legal responses for redressing past abuses, which were to be designed and evaluated in terms of their capacity to entrench democratic stability and the rule of law. ${ }^{5}$ This approach was initially forged by transitologists in the course of the 1980s and at the beginning of the 1990s, during political upheavals in Southern Europe, Latin America and Eastern Europe. ${ }^{6}$ They tackled the relationship between accountability for human rights violations and prospects for democratisation, and drew up prescriptive conclusions as to whether and when to punish crimes committed by former dictatorial regimes. They also pointed to different factors that influence the processes of reckoning with nondemocratic pasts (see below).

In the last two decades transitional justice has turned into an extremely heterogeneous research field, spanning disciplines as diverse as law, political sciences, sociology, psychology, anthropology and history. The impact of transitology on the development of transitional justice remained, however, substantial until the first decade of this century, especially in the field of political science and law. On the one hand, the relationship between justice, the rule of law and democratisation became a core topic of transitional justice. The processes of "coming to terms with the past" continued to be assessed in connection with their consequences for democratic 
consolidation. ${ }^{7}$ On the other hand, the factors and categories invoked by transitologists to explain and predict the course of democratisation were borrowed, updated and refined by various transitional justice scholars in the attempt to apply them to their own research field. ${ }^{8}$ Moreover, as in the case of theories of democratic transitions, researches into the question of "dealing with the past" were often sponsored by governmental (mainly the US) or intergovernmental organisations (such as the United Nations, World Bank or European Union), with the aim of producing standard references and "best solutions" for transitional justice, in accordance with the political constraints of transition.

In this article I critically examine the role and limits of transitology in framing transitional justice studies after the breakdown of authoritarian regimes in Southern Europe, Latin America and Eastern Europe. I focus on the main theoretical and methodological approaches that have been pioneered by transitologists and developed subsequently by transitional justice scholars. My study is by no means an exhaustive review of the entire transitional justice literature. Constructing a bibliographical essay to account for all approaches and studies on the topic would be a major undertaking and beyond the scope of this article. The article engages only with an analysis of ideas and debates inherited by transitional justice studies from transitology. It mainly focuses on political science and law approaches, but addresses also critiques formulated by historians and sociologists. As transitology has dealt almost exclusively with forms of domestic retributive justice (criminal trials and purges undertaken in national settings), I have narrowed the scope of my analysis to such mechanisms, and set to one side the debates relating to international criminal law or to distributive and truth-oriented policies (such as rehabilitations and reparation programmes, truth commissions or policies of memorialisation).

The major topics identified and discussed here are: (1) the connections between justice for past abuses and democratisation, (2) the determinants of transitional justice and (3) the relationship between accountability and the passage of time. I argue that while transitology has nurtured important research initiatives in the field of transitional justice, its approaches have serious shortcomings. First, because transitology sought to formulate guidelines for installing and consolidating democracy, its approaches became prescriptive, rather than analytical and comprehensive. They remained shortterm in focus, and often dehistoricised social phenomena. Second, in adopting a teleological perspective on transitions supposedly bound for democracy, they overlooked comparisons and interconnections between transitional justice processes originating in democratic contexts and those arising from dictatorial settings. Third, in their attempt to build general typologies and establish causalities between types of dictatorial regimes, exit modes from authoritarianism and justice mechanisms, transitological approaches often failed to explain the actual peculiarities of national cases. Also, because they analysed transitions almost exclusively as domestic/national processes, they underestimated the role of international contexts and transnational interactions.

\section{Transitional justice and democratisation}

Within the framework of democratic transition and consolidation, one important question was: how should societies deal with crimes committed by the previous dictatorial regimes in order to ensure 
justice and democratic stability? Two different answers divided both scholars and political elites. The first one held that retributive justice for past abuses might jeopardise the new democratic project, and that an amnesty might be a more appropriate policy for ensuring a peaceful transition from authoritarian rule. Conversely, the second one argued that the arraignment of former dictatorial leaders would strengthen the democratic values of human rights and the rule of law, being thus an essential part of the democratisation process.

According to the first perspective, trials and purges might antagonise the supporters of the ousted regime and push them into violent contestation of the new political order. ${ }^{10}$ While ideally violations of human rights should be prosecuted, governments must limit trials when they endanger democratic consolidation. This was particularly asserted for transitions where a dominant military elite had conditionally transferred power in return for amnesty, as was the case with Argentina and Chile in the 1980s." Issues of regional security are also evoked as an argument against trials and purges. In circumstances where there is a fragile security context (for example, Greece during the Cyprus crisis), retributive justice is halted in order to avoid internal divisions and the alienation of the army. ${ }^{12}$ In cases of transitions from war to peace, certain scholars surmise that prosecutions exacerbate political tensions between the opposed camps and risk causing further atrocities. Amnesties, or simply turning a blind eye to past abuses, are considered more instrumental in achieving peace and democracy. ${ }^{13} \mathrm{As}$ far as purges (or lustration in Eastern Europe) are concerned, they are deemed to be at odds with the democratic project, because they raise two major problems of the rule of law. On the one hand, they are based on the principle of collective guilt and disqualify people because of their political beliefs. On the other, they are often conducted by extrajudicial bodies following extrajudicial procedures. ${ }^{14}$ According to this perspective, states should thus not focus on backward-looking measures, but on forward-looking goals such as the establishment of a constitutional regime, and institutional and economic reform. ${ }^{15}$

Conversely, other scholars argue that, despite the risks involved in criminal procedures, the "least worst" strategy is to prosecute and punish. ${ }^{16}$ Trials based on due process affirm a new legal order entrenched in the rule of law. They bolster people's trust in justice, and undermine the culture of impunity with regard to political crimes and abuses..$^{17}$ Ignoring gross violations of human rights would instead shore up the sense of immunity of the old elites. It would bury not only the past, but also the ethical values that a society needs to ensure its democratic future. In the context of the late twentieth century, these values were defined in terms of political liberalism, civil and political rights, and individual accountability. In post-1989 Eastern Europe, lustration was defended as a solution designed to minimise the influence of the former communist, undemocratic elites on the democratising present. ${ }^{18}$

The attempts to build a theory of retributive transitional justice and democratisation are problematic for several reasons. First, local particularities result in different outcomes that can become "usable pasts" for the advocates both of trials and of amnesties. Argentina after 1983 became the key example cited by those arguing against prosecutions. The arraignment of army officers for crimes committed during the Dirty War provoked military rebellions, which in their turn led democratic president Raúl Alfonsín to limit and finally to put an end to criminal prosecutions. ${ }^{19}$ Postdictatorial Greece was for its part invoked as a successful example of retributive justice. Between 1975 and 1976, twenty junta members were prosecuted for conducting the military coup of 1967, and 
many other officers and conscripts were judged for violations of human rights committed during the Colonels' regime..$^{20}$ Most transitional justice scholars consider that, in the context of the Cyprus crisis, the decision of Karamanlis' new democratic government to limit the number of purges and trials was taken in order to avoid disaffection and hostility within the army. However, they also concede that prosecutions curbed the power of the former military elites and helped to consolidate the democratic project. ${ }^{21}$ The Argentinian and Greek cases are only two examples that show that attempts to discern general causalities between justice and democratisation are frequently hampered by the diversity of national/local historical contexts, which give rise to different outcomes.

Second, theories of democratic transitions, and transitional justice studies inspired by them, adopt a short-term perspective on the postdictatorial transformations. They do not take into account the fact that arrangements that seem to have positive effects in the first phase of transition may have negative consequences in the longer run. In Chile, for example, the absence of prosecutions was deemed in the 1990s to have favoured democratic stability. ${ }^{22}$ More recent studies, however, argue that impunity delayed democratisation because it allowed the army to postpone its reform and to retain a strong influence over Chilean society. ${ }^{23}$ There are also controversial debates about the long-term consequences of lustration in Eastern Europe. In the 1990s, Letki considered postcommunist purges in the Czech Republic to have been a success story, since they had minimised the influence of former nomenklatura within society. ${ }^{24}$ Choi and David likewise argue that the dismissal of former elites fostered trust in the new government. However, they also show that in the long run lustration did not have "a negative effect on trust in the tainted official", but on the contrary enforced trust in former communist elites.$^{25}$ What is more, one problem that social scientists constantly encounter is the fact that the relationship between two social facts might be attributed to an unnoticed third factor. In the case of retributive justice and democratisation, it is hard to isolate the impact of trials and purges from that of institutional reforms, economic conditions or international contexts.

Third, most of the studies that deal with the relationship between justice and democratisation inherit from transitology a highly prescriptive approach to social phenomena. The main focus is often on rationalising the "proper solutions" that are supposed to lead in the "right direction", rather than on providing a comprehensive account of what has occurred. ${ }^{26}$ This implies an evaluation of past events according to present criteria. It also leads to a tendency to dehistoricise social facts and to ignore the influence of long-term historical processes. A wider temporal space is usually lacking in such analyses.

\subsection{Transitional justice beyond the democratisation framework}

Rooted in the theories of democratic transitions, transitional justice as an academic discipline is nowadays confined to countries that aspire to become constitutional democracies. The concept implies an understanding of justice framed by the Western vision of the rule of law and by a teleological perspective on transitions supposedly bound for democracy. The origins of the "justice cascade" or of the "age of accountability" are identified in events following the collapse of dictatorships in Greece or Argentina. ${ }^{27}$ Consequently, the bulk of the scholarly literature focuses exclusively on countries from the "third wave" of democratisation. The handful of studies that widen the perspective and include post-Second World War trials and purges do, however, limit their analysis to meas- 
ures adopted in Western democratic countries. ${ }^{28}$ Processes originating in the state-socialist world or in other authoritarian settings are excluded from the transitional justice concept and literature.

A broader framework - over and above its purportedly necessary connection to democratisation - would be more heuristic for understanding how the issue of dealing with the past was comprehended in different epochs or ideological contexts. To what extent did debates about retroactivity, purges or disqualifications differ from democratic to authoritarian settings, and how did they influence each other? In the field of international human rights law, a long-term approach - extending beyond the boundaries of the liberal democracies - would allow significant insights into the role of authoritarian regimes (state-socialist or other) in calling for the adoption of international conventions regarding genocide, war crimes and crimes against humanity. It would also explain why certain ideas originating in, or strongly endorsed by, the state-socialist world won the backing of the West (for example, the 1948 UN Convention for the Prevention and Punishment of the Crime of Genocide or the 1967 International Covenant of Economic, Social and Cultural Rights), while others, such as the 1968 UN Convention on War Crimes and Crimes against Humanity, or the 1973 UN Convention on the Suppression and Punishment of the Crime of Apartheid, failed to attain global momentum? And finally, to what extent and how were laws promoted in the international arena by the socialist states used after 1989 in order to punish crimes committed by these same regimes?

Answers to these questions could better clarify the global, entangled evolution of ideas about accountability in times of radical political transformation since 1945. They would also underline the interconnections between post-Second World War justice initiatives in Europe and Asia, processes originating in the state-socialist and the postcolonial world, and liberal "third wave" approaches to transitional justice. They could explain why certain norms and practices acquired global or transregional importance, and, why others remained locally embedded or failed to make their mark in international practices.

\section{The determinants of transitional justice}

Another important contribution of transitology to the field of transitional justice concerns the factors that shape the processes of dealing with the past. Three main determinants invoked by transitologists to explain and predict the course of democratisation were also applied to transitional justice policy making: (1) the type of transition; (2) the nature of the previous regime; and (3) the international context. While most scholars analyse these aspects as interrelated factors, a certain hierarchy among them is also posited.

\subsection{Transitional justice and the exit from authoritarianism}

Among the first to dwell on the topic, Huntington identified the exit mode from authoritarian rule as the main variable that influences transitional justice. He classified the "third wave" of transitions into three categories, each of which would have consequences for the future of democracy: replacements, transformations and transplacements. ${ }^{29}$ Rustow, for his part, wrote of overthrow, reform 
and compromise..$^{30}$ The first (replacement or overthrow) involves a revolutionary overthrow of the authoritarian regime. The second (transformation or reform) is driven by reformers within the authoritarian regime. The third (transplacement or compromise) involves negotiations between the opposition and the authoritarian elites. According to Huntington, replacements of the old regime generate harsher manifestations of postdictatorial justice, while transformations and transplacements involve more indulgent policies towards the past. ${ }^{11}$ Using Rustow's categories, Huyse supports the same argument. ${ }^{32}$

This approach is problematic from several points of view. First, creating typologies of exit modes from authoritarianism often empties transition processes of their complexity, "giving them the simplicity of essences" and endowing them with a "blissful" but misleading clarity. ${ }^{33}$ For example, the ways Argentina and Romania exited authoritarianism in 1983 and 1989, respectively, both included in the replacement/overthrow category, were in fact quite different. Even if the Argentinian military junta lacked popular support, or a reformist movement, its leaders peacefully initiated and negotiated the transition. ${ }^{34}$ By contrast, the Romanian communist elites violently suppressed the December 1989 mass protests, causing the death of at least 1,100 people. ${ }^{35}$ Also, defining Bulgaria as a case of transformation overlooks complex interactions between governmental elites, dissidents and the masses. In 1989, reformist elites within the communist party overthrew Todor Zhivkov, without however immediately initiating a transition to political pluralism. Anticommunist mass protests erupted after Zhivkov's fall and forced the new communist leaders to enter into negotiations with the opposition, and finally to hold free elections ${ }^{36}$ Establishing categories of exit modes often leads scholars to neglect the actual peculiarities of national cases.

Second, this approach analyses transitional justice as if it were a process driven exclusively by political elites, paying little attention to other social actors. Protests, movements and the "resurrection of civil societies" in general are seen as short-lived and disruptive episodes, having relatively little impact on the course of transition. ${ }^{37}$ Recent scholarship on Latin America and Eastern Europe emphasises, however, that citizen-led claims or pressure from NGOs are a powerful motor of transitional justice. ${ }^{38}$ The focus on elite negotiations also ignores the role of the judiciary as a relatively autonomous agency. Justice is here viewed as an exclusive product of politics. The specific dynamics of law, which, although socially embedded, obeys its own procedures and temporalities, are overlooked. ${ }^{39}$ The analysis of transitional justice only in terms of elite games and negotiations oversimplifies both politics and law. A more heuristic framework would focus on how other actors, of many different kinds, understand and engage in transitional justice processes.

Third, the exit mode factor fails to explain by itself the so-called "second wave of dealing with the past" that occurred in Eastern Europe, Latin America and even in Spain many years after the fall of the dictatorship. In Argentina in 2005, for example, more than 20 years after the transition, the supreme court declared as unconstitutional and repealed the amnesty laws passed by the Alfonsin administration in 1986. Since that date, more than 50 military officers have been convicted of murder and of perpetrating forced disappearances. ${ }^{40}$ Likewise, in Chile and Guatemala, trials were only staged ten full years after the collapse of the dictatorship. ${ }^{41}$ By the same token, in Eastern Europe many countries adopted lustration laws some 10 or 15 years after the fall of the dictatorial regime. Among them: Poland in 1997 (implemented in 1999), Romania in 2000 and Bulgaria in 2006.42 
These critiques do not imply that the type of transition does not count at all. Initial arrangements have consequences for future events, but they may be reversed if or when other factors come into play. The concept of exit mode, as conceptualised by transitologists, is static and deterministic, since it assumes that the initial configuration remains a stable variable and is not subject to further transformation. It ignores the fact that transitions are by definition dynamic and uncertain processes and can have indefinite outcomes. Moreover, extrication paths are considered to be a precise temporal sequence within the transition process. But how can we determine and isolate such sequences? When does transition begin and when does it end?

\subsection{Transitional justice and the legacy of the past}

Another approach, pioneered by transitologists like O'Donnell and Schmitter, Linz and Stepan, or Kitschelt et al., argues that the nature of the previous dictatorial regime is the major factor that shapes democratisation and transitional justice. ${ }^{43}$ In their view, the greater the degree of liberalisation of the previous regime, the greater the tendency to forget past abuses and to embrace a moderate model of retributive justice. The scale of the repression, the types of crime committed, the duration of the former dictatorial rule, its degree of militarisation, or its degree of legitimacy through societal cooptation are all factors evoked nowadays by transitional justice scholars. ${ }^{44}$

However, the "legacy of the past approach" is generally confined to the nature of the former regime and does not identify factors that go beyond that period. Stan's analysis of Eastern Europe is one of the few exceptions. While she concludes that "the scope and pace of reckoning with the past are strongly linked to the relationship between regime and opposition during communism and post-communism", she also underlines the importance of a country's pre-communist experience of political pluralism..$^{45}$ Huyse, for his part, draws attention to the fact that earlier experiences of dealing with the past may influence present forms of accountability, but he does not develop this point. ${ }^{46}$ From a more analytical perspective, Mouralis and Weinke underline how the post-1945 West German experience of reckoning with national socialism had a strong impact after 1990 on retributive justice regarding crimes committed by the GDR authorities. ${ }^{47}$ However, even these studies focus mainly on political rather than sociohistorical aspects. The role of legal culture in retrospective justice, or the role of a nation's master historical narrative in shaping justice, are generally overlooked in the literature.

Moreover, as in the case of perspectives focusing on exit modes, so too an approach stressing "the legacy of the past" cannot fully account for the continuity or resurgence of transitional justice measures long after the collapse of the dictatorial regimes. This is why authors such as Welsh, Barahona de Brito et al., Nalepa, or Williams, Fowler and Szczerbiak introduced a new variable that explains the course of accountability, namely, the postauthoritarian political competition. While the nature of the previous regime or the international ideological context count for something, the balance of power between the old and the new political elites, the coalition-building strategies and the elite tactics of using the past to acquire legitimacy in the new democratic order represent the major determinants that influence the course of justice. This approach can also shed light on the constant re-emergence of the "issue of the past" on the political agenda even many years after the fall of the dictatorship. 48 
More importantly, both "exit mode" and "legacy of the past" approaches analyse transitions almost exclusively as domestic processes. They examine nation-states as fixed and isolated entities, underestimating the impact of the international context or that of transnational movements, transfers, and circulation of ideas. They thus neglect the fact that policies of "dealing with the past" may well be adopted in a country many years after transition because of international pressure, or because national elites draw inspiration from similar processes that have been implemented in a neighbouring state (see below).

\subsection{Transitional justice and the international context}

Transitologists have generally considered international factors (such as the international/regional security context or the global regime of human rights) as secondary determinants of political transitions and of processes of dealing with the past. ${ }^{49}$ Transitional justice policies, it was argued, are primarily shaped by the domestic political context (and by a national historical framework of reference) rather than by international norms and pressures. This argument continues to be supported by most of the comparative approaches to the topic that examine local settings as discrete units, and not as interconnected elements within a regional or global history. ${ }^{50}$

An alternative perspective is offered by scholars who try to integrate national cases into broader regional or international contexts. Focusing on the interaction between domestic and international actors and norms, they emphasise how these aspects are mutually constitutive. ${ }^{51}$ First, transitional justice measures are strongly influenced by previous experiences of neighbouring countries. The model of the Argentinian truth commission rapidly spread to Chile and Uruguay and later across continents. Also, the Argentine Forensic Anthropology Team, established in 1986 as the world's first human rights forensic organisation, started to cooperate with human rights activists from neighbouring states, and later expanded its activity in nearly 30 countries throughout the world. ${ }^{52}$ Calls for lustration in Romania, Bulgaria or Poland evoked throughout the 1990s the measures already adopted in Germany in 1990 and Czechoslovakia in 1991. Mutual influences can be found also at a transregional level. Eichmann's trial revived the debates about the Holocaust in Europe. ${ }^{53} \mathrm{Also}$, starting with the 1990s, truth commissions expanded from Latin America to Africa, and Asia. By mid-2004 a total of 36 truth or historical commissions had been established worldwide. ${ }^{54}$ In-depth studies of these transregional transfers, however, remain to be written.

Second, Sikkink and Roht-Arriaza talk about a so-called "boomerang model" whereby external agents are used by local activists to amplify and transmit to national authorities their accountability claims..$^{55}$ Regional courts, such as the Inter-American Court of Human Rights (IACHR) or the European Court of Human Rights (ECtHR), played an important role in enhancing accountability in postdictatorial Latin America and postcommunist Eastern Europe. The IACHR blocked, for example, the application of amnesty laws for crimes against humanity in Peru and Guatemala. ${ }^{56}$ The ECtHR obliged the Romanian state to extend the statute of limitations for crimes committed during the December 1989 events, arguing that in many cases investigations had been postponed for political reasons. ${ }^{57}$ Another important mechanism of the "boomerang model" was universal jurisdiction.$^{58}$ It permitted Latin American victims and activists to lodge criminal complaints in European countries such as Spain, France or Belgium. Augusto Pinochet's arrest in London in 1998, the indictment of former Guatemalan dictator 
Efraín Ríos Mont by a Spanish court in 2006, or the conviction of former Argentinian military officer Adolfo Scilingo in 2006, also by a Spanish court, had an important impact on the activity of domestic courts in Latin America. Immediately after these events, prosecutions emerged or re-emerged on the agenda of national tribunals in Chile, Argentina and Guatemala.

Third, direct international pressures enhance accountability. Post-1945 West Germany is a good example. In 1968 and 1979, due to lively debates within the UN and to demands coming from both Eastern (USSR and Poland) and Western European countries (France and Belgium), the Bundestag first prolonged and, ultimately, lifted the statutes of limitations for murder in order to allow the continuation of trials and criminal investigations into national socialist crimes ${ }^{59}$ More recently, through the creation of international tribunals (former Yugoslavia, Rwanda, Cambodia, Sierra Leone) and of the International Criminal Court, the United Nations compelled national governments to deal with heinous crimes. The European Union also played an important role in states of the former Yugoslavia, when it made their admission to full membership conditional on the extradition or arraignment of war criminals. While the success and the effectiveness of these international pressures are often questioned, there is no doubt that they exercise important influence at a local level. ${ }^{60}$

\section{Time in transitional justice}

The relationship between accountability and the passage of time was a third important issue raised by transitologists in the field of transitional justice. Citing the Spanish experience, O'Donnell and Schmitter argued that "the passage of time attenuates the bitterest of memories", and that all political actors can finally agree "not to dig around the past". ${ }^{61}$ Huntington even affirmed that "in new democracies, justice comes quickly or it doesn't come at all". ${ }^{22}$ More than 20 years later, the Southern European, Latin American and Eastern European experiences showed that calls for justice became more likely with the passage of time. Even in Spain, the paradigmatic "model of forgiving and forgetting", the law of historical memory promulgated in 2007, a full 40 years after the transition, allowed the opening of the archives and the identification of the victims of the Franco regime. ${ }^{63}$

This observation about time and transitional justice can be explained on the one hand by the fact that experiences examined by transitologists were very recent, so there was little scope to stand back and take a broader view. On the other hand, however, scholarship on the "third wave" of democratisation (and its subsequent processes of dealing with the past) ignored the post-Second World War European experiences of justice for war crimes and crimes against humanity. The evolution of accountability in post-1945 France or West Germany shows that irruptions of memory and the resurgence of retrospective justice are liable to occur decades after the breakdown of the former regime. In France, despite the amnesties of the early 1950s that put an end to the collaborators' trials, criminal proceedings re-emerged in the 1970s and the 1980s, culminating in the conviction of prominent former Nazis or members of the Vichy elite, such as Klaus Barbie or Maurice Papon. ${ }^{64}$ In West Germany, a culture of impunity with regard to Nazi perpetrators was endorsed by the national judiciary in the 1950s, in response to the internationally imposed Nuremberg trials. Nevertheless, accountability events re-emerged in 1957 with the Einsatzgruppen trials, in 1963 
with the Auschwitz trials, and in 1979 with criminal investigations into cases of maladministration of justice by the national socialist judiciary. ${ }^{65}$

Historical approaches to memory and transitional justice illustrate the fact that the past can continue to "irrupt" in the present. ${ }^{66}$ According to Wouters, even in societies that "succeeded in building a strong national consensual regime, memory incidents stay present right under the surface ... Alternative memories were never buried or forgotten but simply dormant or invisible (meaning not easily perceivable)" ${ }^{67}$ Bevernage, relying to Derrida's and Althusser's works, thus argues that the past continues to disrupt the present, simply because historical processes resist "being frozen" and always contain "delays, survivals, and unfinished projects". ${ }^{68}$ While the passage of time does indubitably make retributive justice more difficult (for legal or biological reasons), trials may occur many years after transition. The generational shift, the evolution of the international human rights regime, the experience of neighbouring countries, and the emergence of a new domestic political context, are all elements that can contribute to accountability or memory shifts. ${ }^{69}$ Thus, the passage of time does not necessarily alleviate the bitterest of memories. Although the preoccupation with justice and memory is sometimes replaced by other social and political concerns related to the present context, claims for accountability and remembrance can resurface and have an impact several decades after the collapse of dictatorial regimes.

\section{Conclusions}

In the 1980s and 1990s, theories of democratic transitions nurtured important theoretical debates about postdictatorial accountability in the context of the "third wave" of democratisation. On the one hand, scholars investigated the relationship between retributive justice and democratic stability and consolidation. On the other, transitologists were the first to interrogate the determinants of transitional justice, with a view to establishing causalities between types of dictatorial regimes, exit modes from authoritarianism, and justice mechanisms. Finally, they tackled the relationship between justice and the passage of time. These topics remain even today central themes of transitional justice studies. However, the approaches pioneered by transitologists, and embraced later by other scholars (especially in the field of political science and law), are not without their flaws.

Most of the studies that deal with the relationship between justice and democratisation inherited from transitology a normative approach to social phenomena. The purpose was not only to offer a comprehensive analysis, but also to formulate guidelines for installing and consolidating democracy. This approach favoured prescription instead of inclusive accounts of events, and it often rationalised a posteriori the "right solutions" supposed to head in the "right direction".70

These studies adopted a teleological perspective on transitions supposedly bound for democracy, and overlooked similar transitional justice processes unfolding in dictatorial settings. It consequently ignored comparisons and connections between the liberal "third way" approaches to transitional justice and processes occurring in other contexts such as postcolonial Africa or the state-socialist world. A broader understanding of transitional justice beyond the framework of 
democratic transformation would shed light on the global interactions of ideas about transitional accountability between 1945 and the present day.

Moreover, approaches inspired by transitology remained short-term in focus and lacked "historical depth". Studies that emphasised the impact of the exit mode from authoritarianism ignored structural constraints and conceptualised the "inaugural configurations" of democracy as ahistorical moments. They also analysed transitional justice merely as a product of politics, and paid almost no attention to legal, cultural and psychological aspects that were constitutive parts of law. "Legacy of the past" approaches overlooked the rational choices of various actors and opted for a sort of "rudimentary historical determinism", ${ }^{71}$ which was rooted in the nature of the former nondemocratic regime. They neglected longue durée dynamics, ignoring the pre-dictatorial temporal frameworks.

The attempt to establish general typologies and causalities often failed to account for and explain local particularities. Case studies of different countries or regions have subsequently shown just how crucial the historicising of national/local processes within a wider temporality is to understanding transitional justice. Such an approach is itself not without its dangers, however, as it runs the risk of becoming too particularistic and overdetailed.

Finally, because they focused on transitions as discrete units, theoretical perspectives inherited from transitology underestimated the role of international pressure, as well as the importance of the transnational circulation of ideas. Domestic trials and purges were rarely integrated into a broader regional and global perspective, whereby national and international processes are viewed as mutually constitutive.

\section{NOTES}

* I I am grateful to the Leverhulme Trust, which supports my research within the project "1989 after 1989: The Fall of State-Socialism in Global Perspective", and to the Institute for European Global Studies, Basel University, for the postdoctoral fellowship awarded in 2013. I thank James Mark, Ned RichardsonLittle, Bogdan lacob and the reviewers of Historein for their valuable suggestions.

1 For the history and critique of transitology, see Guy Hermet, "Le charme trompeur des théories: un état des travaux," in Démocraties d'ailleurs. Démocraties et démocratisations hors de l'Occident, ed. Christophe Jafferot (Paris: Karthala, 2000); Michel Dobry, "Les voies incertaines de la transitologie: Choix stratégiques, séquences historiques, bifurcations et processus de la Path Dependence," Revue Française de Science Politique 50/4-5 (2000): 585-614.

2 For a history and critique of transitional justice academic field, see Liora Israel and Guillaume Mouralis, eds., Dealing with Wars and Dictatorships: Legal Concepts and Categories in Action (The Hague: Springer, 2014).

3 Peter Novick, The Resistance versus Vichy: The Purge of Collaborators in Liberated France (New York: Columbia University Press, 1968); Hannah Arendt, Eichmann in Jerusalem (London: Faber and Faber, 1963); Fritz Weinschenk, "Nazi before German Courts: The West German War Crimes Trials," The International Lawyer 10/3 (1976): 515-529.

4 Guillaume Mouralis, "The Invention of 'Transitional Justice' in the 1990s," in Dealing with Wars, eds. Israel and Mouralis, 83-100. 

Guillermo O'Donnell and Philippe C. Schmitter, Transitions from Authoritarian Rule: Tentative Conclusions about Uncertain Democracies (Baltimore: Johns Hopkins University Press, 1986); Samuel Huntington, The Third Wave: Democratization in the Late Twenty Century (Oklahoma: University of Oklahoma Press, 1991).

7 See Neil J. Kritz, ed., Transitional Justice: How Emerging Democracies Reckon with Former Regimes (Washington DC: United States Institute of Peace Press, 1995); James McAdams, ed., Transitional Justice and the Rule of Law in New Democracies (Notre Dame: University of Notre Dame Press, 1997); Alexandra Barahona de Brito, Carmen Gonzalez-Enriques and Paloma Aguilar, eds., The Politics of Memory: Transitional Justice in Democratizing Societies (Oxford: Oxford University Press, 2001); Tricia D. Olsen, Leigh A. Payne and Andrew G. Wreiter, Transitional Justice in Balance: Comparing Processes, Weighing Efficacy (Washington DC: United States Institute of Peace Press, 2010); Kathryn Sikkink, The Justice Cascade: How Human Rights Prosecutions Are Changing World Politics (New York: WW Norton, 2011).

8 See Nadia Nedelsky, "Divergent Responses to a Common Past: Transitional Justice in the Czech Republic and Slovakia," Theory and Society 33/1 (2004): 65-115; Monika Nalepa, Skeletons in the Closet: Transitional Justice in Post-Communist Europe (Cambridge: Cambridge University Press, 2010); Barahona de Brito, Gonzalez-Enriques and Aguilar, eds., Politics.

9 See for example the programmes and publications of the United States Institute of Peace, among which Kritz, ed., Transitional, or US Institute of Peace, "Transitional Justice: Information Handbook," 2008, accessed 14 Nov. 2014, http://www.usip.org/sites/default/files/ROL/Transitional_justice_final.pdf.

10 Huntington, Third Wave, 211-231; Linz, Crisis.

11 Carlos Santiago Nino, "The Duty to Punish Past Abuses of Human Rights Put Into Context: The Case of Argentina," The Yale Law Journal 100/8 (1991): 2619-2640; Jaime Malamud-Goti, "Transitional Governments in the Breach: Why Punish State Criminals?," Human Rights Quarterly 12/1 (1990): 1-16; José Zallaquett, "Balancing Ethical Imperatives and Political Constraints: The Dilemma of New Democracies Confronting Past Human Rights Violations," Hastings Law Journal 43/6 (1992): 1425-1438.

12 See for example Stefanos Katsikas, "Transitional Justice after the Collapse of Dictatorship in Greece (1974-2000)," in Transitional Justice and Memory in Europe (1945-2013), ed. Nico Wouters (Cambridge: Intersentia, 2014), 259-287.

13 Jack Snyder and Leslie Vinjamuri, "Trials and Errors: Principles and Pragmatism in Strategies of International Justice," International Security 28/3 (2003-2004): 5-44.

14 See Luc Huyse, "Justice after Transition: On the Choices Successor Elites Make in Dealing with the Past," Law \& Social Inquiry 20/1 (1995): 51-78; Lavinia Stan, ed., Transitional Justice in Eastern Europe and the Former Soviet Union (London: Routledge, 2008).

15 Bruce Ackermann, The Future of Liberal Revolution (New Haven: Yale University Press, 1992); Huntington, Third Wave; Snyder and Vinjamuri, "Trials."

16 O'Donnell and Schmitter, Transitions from Authoritarian Rule, 28-36.

17 Kathryn Sikkink, Justice Cascade; Diane F. Orentlicher, "Settling Accounts: The Duty to Prosecute Human Rights Violation of a Prior Regime," The Yale Law Journal 100/8 (1991): 2537-2615; John Borneman, Settling Accounts: Violence, Justice and Accountability in Post-socialist Europe (Princeton: Princeton University Press, 1997). 
18 Natalia Letki, "Lustration and Democratisation in East-Central Europe," Europe-Asia Studies 54/4 (2002): 535.

19 Carlos H. Acuña and Catalina Smulovitz, "Guarding the Guardians in Argentina: Some Lessons about the Risks and Benefits of Empowering the Courts," in Transitional Justice, ed. James McAdams, 93-122; Nino, "Duty"; Alexandra Barahona de Brito, "Truth, Justice, Memory and Democratization in the Southern Cone," in Politics, eds. Barahona de Brito, Gonzalez-Enriques and Aguilar, 119-160.

20 The exact number of prosecutions is uncertain. Psomiades estimates that between 100 and 400 trials were held in various jurisdictions, while Alivizatos and Diamandouros refer to less than 100 prosecutions. Harry Psomiades, "Greece: From the Colonel's Rule to Democracy," in From Dictatorship to Democracy: Coping with the Legacy of Authoritarianism and Totalitarianism, ed. John H. Herz (Westport: Greenwood, 1982), 262-265; Nicos C. Alivizatos and P. Nikiforos Diamandouros, "Politics and the Judiciary in the Greek Transition to Democracy," in Transitional Justice, ed. James McAdams, 27-60.

21 P. Nikiforos Diamandouros, "Regime Change and the Prospects for Democracy in Greece: 1974-1983," in Transitions from Authoritarian Rule: Southern Europe, eds. Guillermo O'Donnell, Philippe C. Schmitter and Laurence Whitehead (Baltimore: Johns Hopkins University Press, 1986), 154-164; Psomiades, "Greece," 264-265; Katsikas, "Transitional Justice," 283-284.

22 Zallaquett, “Balancing."

23 Mary H. Spooner, The General's Slow Retreat: Chile after Pinochet (Berkeley: University of California Press, 2011).

24 Letki, "Lustration."

25 Susanne Y.P. Choi and Roman David, "Lustration Systems and Trust: Evidence from Survey Experiments in the Czech Republic, Hungary, and Poland," American Journal of Sociology 117/4 (2012): 11921193.

26 Guillaume Mouralis, Une épuration allemande: La RDA en procès 1949-2004 (Paris: Fayard, 2008), 21-22.

27 Sikkink, Justice Cascade.

28 Kritz, ed., Transitional Justice; Huyse, "Justice"; Jon Elster, Closing the Books: Transitional Justice in Historical Perspective (Cambridge: Cambridge University Press, 2004), 47-78; Wouters, ed., Transitional Justice.

29 Huntington, Third Wave.

30 Dankwart A. Rustow, "The Surging Tide of Democracy," Journal of Democracy 3/1 (1992): 119.

31 Huntington, Third Wave, 211-231.

32 Opposite to Huntington, Huyse does not make an hierarchy of factors and notes also the great importance of international factors (such as the global concern for human rights or security issues) and of the nature of the former authoritarian regime. Huyse, "Justice."

33 Borneman, Settling Accounts, 27.

34 Marcelo Cavarozzi, "Political Cycles in Argentina since 1955," in Transitions from Authoritarian Rule: Latin America, eds. Guillermo O'Donnell, Philippe C. Schmitter and Laurence Whitehead (Baltimore: Johns Hopkins University Press, 1989), 45-48.

35 Peter Siani-Davies, The Romanian Revolution of December 1989 (Ithaca: Cornell University Press, 2007).

36 Marta Touykova, “La genèse d’un parti successeur en Bulgarie," Raisons Politiques 3 (2001): 127-128. 
37 O'Donnell and Schmitter, Transitions, 55-56. Terry L. Karl and Philippe Schmitter, "From the Iron Curtain to a Paper Curtain: Grounding Transitologists or Students of Postcommunism?" Slavic Review 54/4 (1995): 976.

38 Margaret Keck and Kathryn Sikkink, Activists Beyond Borders: Advocacy Networks in International Politics (Ithaca: Cornell University Press, 1998); Cath Collins, Post-transitional Justice: Human Rights Trials in Chile and El Salvador (University Park: Pennsylvania University Press, 2012); Stan, ed., Transitional Justice; Olivera Simić and Zala Volčič, eds., Transitional Justice and Civil Society in the Balkans (New York: Springer, 2013).

39 Mouralis, Une épuration allemande, 23-25.

40 See Francesca Lessa, Memory and Transitional Justice in Argentina and Uruguay: Against Impunity (New York: Palgrave Macmillan, 2013).

41 See, for example, Collins, Post-Transitional Justice; Naomi Roht-Arriaza, "Genocide and War Crimes in National Courts: the Conviction of Rios Montt in Guatemala and its Aftermath," Insights 17/14 (2013).

42 Stan, ed., Transitional Justice.

43 O'Donnell and Schmitter, Transitions, 28-36; Juan J. Linz and Alfred Stepan, Problems of Democratic Transition and Consolidation: Southern Europe, South America and Post-Communist Europe (Baltimore: Johns Hopkins University Press, 1996); Herbert Kitschelt, Zdenka Mansfeldova, Radoslaw Markowski and Gabor Toka, Post-Communist Party Systems: Competition, Representation and Inter-party Competition (Cambridge: Cambridge University Press, 1999).

44 Jon Elster, "Coming to Terms with the Past: A Framework for the Study of Justice in the Transition to Democracy," Archives européennes de sociologie 39/1 (1998): 7-48; John Moran, "The Communist Torturers of Eastern Europe: Prosecute and Punish or Forgive and Forget?," Communist and Post-Communist Studies 27/1 (1994): 95-109; Herbert Kitschelt, "Formation of Party Cleavages in Post-Communist Democracies: Theoretical propositions," Party Politics 1/4 (1995): 447-472; Nedelsky, "Divergent Responses"; Stan, ed., Transitional Justice.

45 Lavinia Stan, "Determinants of Post-Communist Transitional Justice: An Overview” (paper prepared for the Global Challenges Conference "Justice and Imagination: Building Peace in Post-Conflict Societies," Mount Holyoke College, 28 February-1 March 2014, 15.

46 Luc Huyse, "Comparing Transitional Justice Experience in Europe," in Transitional Justice, ed. Nico Wouters, 361.

47 Mouralis, Une épuration allemande, 269-315; Anette Weinke, "West Germany: A Case of Transitional Justice avant la lettre?," in Transitional Justice, ed. Nico Wouters, 25-55.

48 Kieran Williams, Alks Szczerbiak and Brigid Fowler, "Explaining Lustration in Eastern Europe: A Post-communist politics approach," SEI Working Paper 62 (2003), accessed 4 Feb. 2009, http://www. sussex.ac.uk/sei/documents/wp62.pdf; Barahona de Brito, Gonzalez-Enriques and Aguilar, eds., Politics; Nalepa, Skeletons; Csilla Kiss, "The Misuses of Manipulation: The Failure of Transitional Justice in Post-Communist Hungary," Europe-Asia Studies 58/6 (2006): 925-940.

49 In the 1990s, only few works adopted an "internationalist approach" on democratic transitions, stressing the role of international contexts, pressures and cooperation: Geoffrey Pridham, Eric Herring, and George Sanford, eds., Building Democracy? The International Dimension of Democratization in Eastern Europe (New York: St Martin's Press, 1994), 7-30. More recent researches pay more attention to regional and international frameworks and constraints. See Jan Zielonka, Democratic Consolidation in Eastern Europe (Oxford: Oxford University Press, 2001). 
50 See, for example, Kritz, ed., Transitional Justice; Stan, ed., Transitional Justice; Nalepa, Skeletons.

51 Sikkink, Justice Cascade; Naomi Roht-Arriaza, The Pinochet Effect: Transitional Justice in the Age of Human Rights (Philadelphia: University of Pennsylvania Press, 2005); Collins, Post-transitional Justice.

52 Kathryn Sikkink, "From Pariah State to Global Protagonist: Argentina and the Struggle for International Human Rights," Latin American Politics and Society 50/1 (2008): 8-11.

53 Annette Wieviorka, Le procès Eichmann (Paris: Editions Complexe, 1989), 117-136.

54 Sikkink, "From Pariah," 8.

55 Keck and Sikkink, Activists; Roht-Arriaza, The Pinochet Effect.

56 Sikkink, "From Pariah," 13-14.

57 Eva Brems, "Transitional Justice in the Case Law of the European Court of Human Rights," The International Journal of Transitional Justice 5/2 (2011): 287.

58 Stephen Macedo, ed., Universal Jurisdiction: National Courts and the Prosecution of Serious Crimes Under International Law (Philadelphia: University of Pennsylvania Press, 2004).

59 Robert A. Monson, "The West German Statute of Limitations on Murder: A Political, Legal, and Historical Exposition," American Journal of Comparative Law 30/4 (1982): 605-615.

60 See, for example, Jane Stromseth, "Justice on the Ground: Can International Criminal Courts Strengthen Domestic Rule of Law in Post-Conflict Societies?" Hague Journal on the Rule of Law 1 (2000): 87-97; Eszter Kirs, "Limits of the Impact of the International Criminal Tribunal for the Former Yugoslavia on the Domestic Legal System of Bosnia and Herzegovina," Goettingen Journal of International Law 3/1 (2011): 397-416; Sigall Horovitz, "How International Courts Shape Domestic Justice: Lessons from Rwanda and Sierra Leone," Israel Law Review 46/3 (2013): 339-367.

61 O'Donnell and Schmitter, Transitions, 29.

62 Huntington, Third Wave, 228.

63 Paloma Aguilar and Clara Ramirez-Barat, "Amnesty and Reparations without Truth and Justice in Spain," in Transitional Justice, ed. Nico Wouters, 221.

64 Henry Rousso, The Haunting Past: History, Memory and Justice in Contemporary France (Philadelphia: University of Pennsylvania Press, 2002).

65 See Weinke, "West Germany."

66 Rousso, Haunting Past; Wouters, ed., Transitional Justice; Richard Ned Lebow, Wulf Kansteiner and Claudio Fogu, eds., The Politics of Memory in Postwar Europe (London: Duke University Press, 2006).

67 Wouters, ed., Transitional Justice, 408.

68 Berber Bevernage, "Time, Presence, and Historical Injustice," History and Theory 47/2 (2008): 166.

69 Wouters, ed., Transitional Justice, 402-407.

70 Israel and Mouralis, Dealing, 5.

71 Dobry, “Les voies," 590. 